\title{
Lipids in metabolic health and disease
}

Citation for published version (APA):

Glatz, J. F., de Groot, R. H. M., Hesselink, M. K. C., \& Schrauwen, P. (2011). Lipids in metabolic health and disease. Prostaglandins Leukotrienes and Essential Fatty Acids, 85(5), 195. https://doi.org/10.1016/j.plefa.2011.04.006

Document status and date:

Published: 01/01/2011

DOI:

10.1016/j.plefa.2011.04.006

Document Version:

Publisher's PDF, also known as Version of record

Document license:

Taverne

Please check the document version of this publication:

- A submitted manuscript is the version of the article upon submission and before peer-review. There can be important differences between the submitted version and the official published version of record.

People interested in the research are advised to contact the author for the final version of the publication, or visit the DOI to the publisher's website.

- The final author version and the galley proof are versions of the publication after peer review.

- The final published version features the final layout of the paper including the volume, issue and page numbers.

Link to publication

\footnotetext{
General rights rights.

- You may freely distribute the URL identifying the publication in the public portal. please follow below link for the End User Agreement:

www.umlib.nl/taverne-license

Take down policy

If you believe that this document breaches copyright please contact us at:

repository@maastrichtuniversity.nl

providing details and we will investigate your claim.
}

Copyright and moral rights for the publications made accessible in the public portal are retained by the authors and/or other copyright owners and it is a condition of accessing publications that users recognise and abide by the legal requirements associated with these

- Users may download and print one copy of any publication from the public portal for the purpose of private study or research.

- You may not further distribute the material or use it for any profit-making activity or commercial gain

If the publication is distributed under the terms of Article $25 \mathrm{fa}$ of the Dutch Copyright Act, indicated by the "Taverne" license above, 
Editorial

\section{Lipids in metabolic health and disease}

This special issue of PLEFA contains a selection of original research papers and brief surveys presented at the ninth biennial Congress of the International Society for the Study of Fatty Acids and Lipids (ISSFAL), held in Maastricht, the Netherlands from May 29 to June 2, 2010. The theme of the congress was "Lipids in Metabolic Health and Disease". Plenary lectures were given by renowned scientists from around the world, while selected topics were covered in concurrent sessions organised in three tracks: Lipids \& Health, Lipids \& Nutrition, and Biochemistry of Lipids. The Alexander Leaf Distinguished Scientist Award for Lifetime Achievement was presented to Norman Salem, Jr., Ph.D., University of Rochester, NY, for his major contribution to our current knowledge on docosahexaenoic acid (DHA). The winner of the Early Career Award was John Paul SanGiovanni, Ph.D., National Institutes of Health, Bethesda MD, for his studies on the relationship of long-chain polyunsaturated fatty acid intake with pathogenic processes.

A new record was set for total attendance, which amounted to 609 participants from 38 countries. In order to encourage individuals early in their careers to do research in the area of fatty acids and lipids, $40 \mathrm{New}$ Investigator Awards were provided. Nine of them entered a competition which included voting on a ballot form by all delegates. The three winners of the Top New Investigator Award (one for each track) were Giuseppe Astarita, University of California, USA, Mariela Bernabe, University of Mexico, Mexico, and Remko Kuipers, University of Groningen, the Netherlands. Another highlight was a lifely dinner debate where supporters and opponents discussed the issue whether unsaturated or rather saturated fatty acids are beneficial for heart health.

The present issue of PLEFA covers 14 of the major lecture presentations, including those of the three TOP New Investigator Award winners, and illustrates the breadth of topics covered at ISSFAL 2010. It is our sincere hope that this issue will serve as a useful source of information and thus form a stimulus for future fundamental and applied research in the area so as to bring us to a better understanding of the biological effects of fatty acids and lipid metabolism in health and disease.

The 10th Congress of ISSFAL will take place in Vancouver, Canada, May 26-30, 2012, and is organised by a team chaired by Tom Clandinin. The theme of the meeting will be "The Impact of Dietary Fat on Human Health". Located on the west coast of North America, equidistant from Europe and Asia, the modern and multi-cultural city of Vancouver will truly bring an international feeling to the ISSFAL Congress. We anticipate a stimulating meeting on advances in the exciting and continuously expanding field of fatty acid and lipid research.

Jan F.C. Glatz*, Renate H.M. de Groot, Matthijs K.C. Hesselink, Patrick Schrauwen Department of Molecular Genetics, Maastricht University, P.O. Box 616, 6200 Maastricht, The Netherlands E-mail address: glatz@maastrichtuniversity.nl (J.F. Glatz) 